\title{
Increased cerebral and renal endothelial nitric oxide synthase gene expression after cardiopulmonary bypass in the rat
}

C. David Mazer, MD, ${ }^{\mathrm{a}, \mathrm{b}}$ Francoise Briet, PhD, ${ }^{a}$ Katherine R. Blight, MD, ${ }^{a}$ Duncan J. Stewart, MD, ${ }^{c}$ Malcolm Robb, PhD, ${ }^{\mathrm{c}}$ Zhilan Wang, MSc, ${ }^{a}$ Alana M. Harrington, HBSc, ${ }^{a}$ William Mak, PhD, ${ }^{\mathrm{a}, \mathrm{d}}$ Xiaomao Li, PhD, a,d

Gregory M. T. Hare, MD, PhD a,b

Supplemental material is available online.
From the Departments of Anesthesia a and Physiology ${ }^{\mathrm{b}}$ and the Division of Cardiology, ${ }^{\mathrm{C}}$ University of Toronto, St. Michael's Hospital, and the Biotechnology Centre for Applied Research and Training, ${ }^{\mathrm{d}}$ Seneca College, Toronto, Ontario, Canada.

Supported by St Michael's Hospital, Anemia Institute for Research and Education, Physicians' Services Incorporated Foundation, Canadian Anesthesiologists' Society. Dr Hare is a recipient of the Bristol-Myers Squibb-Canadian Anesthesiologists' Society Career Scientist Award.

This work is attributed to the Department of Anesthesia, St Michael's Hospital, University of Toronto.

Presented in part at the Society of Cardiovascular Anesthesiologists Meeting, Miami, Fla, April 29, 2003.

Received for publication Oct 19, 2005; revisions received May 17, 2006; accepted for publication June 13, 2006.

Address for reprints: C David Mazer, MD, Professor, Department of Anesthesia, University of Toronto, St Michael's Hospital, 30 Bond St, Toronto, Ontario, M5B 1W8 Canada (E-mail: mazerd@smh.toronto.on.ca).

J Thorac Cardiovasc Surg 2007;133:13-20

$0022-5223 / \$ 32.00$

Copyright $(92007$ by The American Association for Thoracic Surgery

doi:10.1016/j.jtcvs.2006.06.047
Objective: Hemodilution and endothelial nitric oxide synthase genetic polymorphism may contribute to cerebral and renal injury after cardiopulmonary bypass. This study tested the hypothesis that cardiopulmonary bypass and anemia stimulate an increase in cerebral and renal endothelial nitric oxide synthase gene expression in an experimental model of cardiopulmonary bypass.

Methods: Anesthetized rats underwent a sham procedure without cardiopulmonary bypass (sham, $n=5$ ), normothermic bypass for 1 hour $(\mathrm{CPB}, \mathrm{n}=7$ ), or bypass plus hemodilutional anemia (CPB anemia, $\mathrm{n}=9$ ). After 24 hours of recovery, RNA was extracted from the cerebral cortex, renal cortex, and renal medulla. Quantitative reverse transcriptase polymerase chain reaction was used to assess endothelial nitric oxide synthase messenger RNA levels in brain and kidney tissues.

Results: The hemoglobin concentration of anemic CPB rats was significantly lower than that of nonanemic rats on bypass $\left(64 \pm 5\right.$ vs $\left.99 \pm 8 \mathrm{~g} \cdot \mathrm{L}^{-1}, P<.001\right)$. Cerebral cortical endothelial nitric oxide synthase messenger RNA levels were increased after cardiopulmonary bypass relative to those of the sham group (11.2 \pm 4.2 vs $6.3 \pm 1.5 \mathrm{fg}, P=.031$ ), without a further increase in anemic rats. Renal medullary endothelial nitric oxide synthase messenger RNA levels were significantly higher in the CPB anemia group than in the sham and CPB groups $(7.1 \pm 4.4$ fg vs $1.8 \pm 0.4 \mathrm{fg}$ vs $3.0 \pm 0.6 \mathrm{fg}, P<.001)$. Renal cortical endothelial nitric oxide synthase messenger RNA levels did not change significantly.

Conclusions: Normothermic cardiopulmonary bypass was associated with higher endothelial nitric oxide synthase messenger RNA levels in kidney and brain than was the sham procedure 24 hours after cardiopulmonary bypass. Anemia accentuated the increase in renal medullary, but not cerebral cortical, endothelial nitric oxide synthase expression. These data provide an approach for exploring potential mechanisms by which endothelial nitric oxide synthase may contribute to renal and cerebral dysfunction after cardiopulmonary bypass and anemia.

$\mathrm{N}$ eurologic and renal injury after cardiopulmonary bypass (CPB) causes significant morbidity in patients undergoing cardiac surgery. ${ }^{1-4}$ Recent studies have demonstrated that hemodilution and endothelial nitric oxide synthase (eNOS) gene polymorphisms may contribute to cerebral and renal injury after $\mathrm{CPB} .^{2,4-7}$ Experimental studies have implicated potential mediators of organ injury after $\mathrm{CPB}$, including embolic events, ${ }^{8}$ inflammatory mediators, ${ }^{3}$ neuronal excitotoxicity, ${ }^{9}$ apoptosis, ${ }^{10}$ and inadequate tissue perfusion. ${ }^{7,11,12}$ Inadequacies in organ perfusion during CPB may be exaggerated under extreme conditions, such as low hematocrit, in which tissue oxygen delivery is further compromised. ${ }^{13}$ 


\author{
Abbreviations and Acronyms \\ cDNA $=$ complementary DNA \\ $\mathrm{CPB}=$ cardiopulmonary bypass \\ eNOS = endothelial nitric oxide synthase \\ IP = intraperitoneal \\ IV = intravenous \\ nNOS = neuronal nitric oxide synthase \\ NOS = nitric oxide synthase \\ $\mathrm{PCR}=$ polymerase chain reaction \\ $\mathrm{RT}-\mathrm{PCR}=$ reverse transcriptase polymerase chain \\ reaction \\ VEGF = vascular endothelial growth factor
}

Canada) before surgical incisions were performed. Anesthesia was maintained with $1 \%$ to $2 \%$ isoflurane (Abbott Laboratories, St Laurent, Quebec, Canada). The tail artery was cannulated with a 22-gauge catheter for direct blood pressure measurement and blood sampling for blood gas analysis and measurement of hemoglobin concentration using co-oximetry (Radiometer ALB 500 and OSM 3, London Scientific, London, Ontario, Canada). Heparin (200 IU intravenous [IV]; Leo Pharma, Thornhill, Canada) and cefazolin (10 mg $\cdot \mathrm{kg}^{-1} \mathrm{IV}$; Eli Lilly, Toronto, Ontario, Canada) were given after cannulation of the common jugular vein. Rectal temperature was monitored, and a heating pad and radiant lamp were used to keep the core temperature near $37^{\circ} \mathrm{C}$. Mean arterial pressure, core temperature, arterial blood gases, and co-oximetry measurements were performed and recorded every 15 minutes before, during, and after CPB. A separate group of rats was exposed to $10 \%$ oxygen for 24 hours, without any anesthesia or surgical manipulation (hypoxia, $\mathrm{n}=5$ ). These hypoxic controls were used to provide cerebral cortical tissue to serve as a positive control for hypoxic gene expression (vascular endothelial growth factor, VEGF).

eNOS and neuronal NOS (nNOS), regulate a number of physiologic functions, including cerebral and renal perfusion. ${ }^{14}$ Experimental studies using nonspecific inhibitors of eNOS and nNOS have demonstrated that NOS activity contributes to the regulation of cerebral blood flow during hemodilution, CPB, and after circulatory arrest. ${ }^{15-17}$ However, the specific role of eNOS after CPB has not been fully characterized in an experimental model of CPB.

Clinical studies have implicated acute hemodilutional anemia and eNOS gene polymorphism with renal and cerebral injury after $\mathrm{CPB}$, emphasizing the need to develop experimental models that will help to define the relationship of eNOS and CPB. The main objective of this study was to determine whether $\mathrm{CPB}$ and anemia, in the absence of sternotomy, hypothermia, or cardioplegia, could influence eNOS expression in the brain and kidney 24 hours after CPB.

\section{Materials and Methods}

\section{Animal Model and Surgical Preparation}

All animal protocols were approved by the Animal Care and Use Committee at St Michael's Hospital in accordance with the requirements of the Canadian Animal Care Committee. Male Sprague-Dawley rats (Charles River, St Constant, Quebec, Canada) weighing approximately $400 \mathrm{~g}$ were assigned to one of three groups: sham, $\mathrm{CPB}$, and $\mathrm{CPB}$ anemia. Sham-operated rats underwent all surgical procedures but were not placed on $\mathrm{CPB}$ (sham, $\mathrm{n}$ $=5$ ). $\mathrm{CPB}$ rats were exposed to 1 hour of $\mathrm{CPB}(\mathrm{CPB}, \mathrm{n}=7)$, and $\mathrm{CPB}$ anemia rats underwent 1 hour of $\mathrm{CPB}$ with hemodilutional anemia (CPB anemia, $n=9)$. Anesthesia was induced in all CPB and sham animals with ketamine $\left(100 \mathrm{mg} \cdot \mathrm{kg}^{-1}\right.$ intraperitoneal [IP]; Parke-Davis/Bayer, Toronto, Ontario, Canada) and glycopyrrolate $\left(0.2 \mathrm{mg} \cdot \mathrm{kg}^{-1} \mathrm{IP}\right.$; Sabex, Boucherville, Quebec, Canada). The trachea was intubated with a 14-gauge catheter (BD Biosciences, Mississauga, Ontario, Canada) and the lungs mechanically ventilated with $100 \%$ oxygen using a pressure control ventilator (Kent Scientific, Litchfield, Conn) to maintain a $\mathrm{PaCO}_{2}$ of 35 to $45 \mathrm{~mm} \mathrm{Hg}$. All cannulation sites were infiltrated with $1 \%$ lidocaine (Xylocaine; Astra Pharma Inc, Mississauga, Ontario,

\section{CPB}

An established model of normothermic CPB was used to study the isolated effect of CPB on cerebral and renal eNOS gene expression in the absence of significant stimuli from sternotomy, aortic crossclamp, hypothermia, or cardioplegia-induced cardiac arrest. ${ }^{7,10,13,18}$ Venous access for CPB was obtained by cannulating the right common jugular vein with a modified multiorificed 14gauge catheter (BD Biosciences, modified in our laboratory), which was placed at the junction of the vena cava and right atrium. The venous catheter was connected to a venous reservoir with silicone tubing (Masterflex; Cole-Parmer Instruments, Niles, Ill). Arterial access was achieved by cannulating the left carotid artery with a 20-gauge catheter (BD Biosciences). The CPB circuit was primed with approximately $40 \mathrm{~mL}$ of blood obtained from 2 heparinized donor rats (400 IU $\mathrm{kg}^{-1}$ heparin IV), which were exsanguinated under general anesthesia before the beginning of the experiment. Pentastarch (Pentaspan; Bristol-Myers Squibb, Montreal, Quebec, Canada) was added to the circuit prime to achieve a target hemoglobin concentration of $100 \mathrm{~g} \cdot \mathrm{L}^{-1}$. Throughout the experiment, the hemoglobin was maintained near $100 \mathrm{~g} \cdot \mathrm{L}^{-1}$ in sham and CPB rats. In the CPB anemia group, further hemodilution with pentastarch was performed to a target hemoglobin concentration near $65 \mathrm{~g} \cdot \mathrm{L}^{-1}$. Blood was pumped from the venous reservoir through a modified neonatal membrane oxygenator (Cobe Cardiovascular, Arvada, Colo) using a calibrated roller pump (Masterflex). Oxygenated blood was returned to the animal via the carotid cannula. The target CPB flow rates $\left(150 \mathrm{~mL} \cdot \mathrm{kg}^{-1}\right.$ . $\min ^{-1}$ ) were based on other rat CPB studies and the normal cardiac output of the rat. ${ }^{9,10}$ This previously established and validated model of CPB does not include potential confounders such as sternotomy, cardioplegia, crossclamping, hypothermia, and underlying comorbidities. ${ }^{9,10}$

Before initiation of $\mathrm{CPB}$, the anesthetic was changed from an inhalational anesthetic to an intravenous anesthetic consisting of fentanyl (6-12 $\mu \mathrm{g} \cdot \mathrm{kg}^{-1} \cdot \mathrm{h}^{-1}$; Abbott), midazolam (60-120 $\mu \mathrm{g}$. $\mathrm{kg}^{-1} \cdot \mathrm{h}^{-1}$; Sabex $)$, and cis-atracurium $\left(1-2 \mathrm{mg} \cdot \mathrm{kg}^{-1} \cdot \mathrm{h}^{-1}\right.$; Abbott). After 60 minutes of $\mathrm{CPB}$, the animals were weaned from 
the bypass circuit and protamine $\left(5 \mathrm{mg} \cdot \mathrm{kg}^{-1}\right.$; Sabex $)$ was administered via the jugular vein. The animals were then decannulated and remained anesthetized and ventilated until spontaneous ventilation resumed. Furosemide $\left(0.5 \mathrm{mg} \cdot \mathrm{kg}^{-1} \mathrm{IP}\right.$; Sabex $)$ was administered before extubation. After tracheal extubation, the animals were allowed to recover in an oxygen-enriched environment for 1 to 2 hours before being returned to room air. Free access to food and water was provided during recovery.

The CPB and sham rats underwent identical surgical preparation including cannulation, mild hemodilution, and anesthetic conditions. Thus, after cannulation of the sham rats, the anesthetic was switched to an intravenous technique for 60 minutes, but the rats were not connected to the CPB circuit.

\section{Brain and Kidney Harvesting for RNA Extraction and Reverse Transcriptase Polymerase Chain Reactions (RT-PCR)}

After 24 hours of recovery following CPB or sham operation, rats were anesthetized with ketamine (100 $\mathrm{mg} \cdot \mathrm{kg}^{-1} \mathrm{IP}$; Parke-Davis/ Bayer, Toronto, Ontario, Canada) and then decapitated. Sections of cerebral cortical, renal cortical, and renal medullary tissue were flash frozen in liquid nitrogen within 6 minutes of decapitation and stored at $-80^{\circ} \mathrm{C}$ until RNA extraction was performed. After mechanical disruption by homogenization of about $30 \mathrm{mg}$ of tissue, total RNA was extracted by standard techniques (RNeasy Mini Kit; Qiagen, Mississauga, Ontario, Canada). The optical density 260/280 $\lambda$ was determined with $10 \mu \mathrm{L}$ of sample and the sample was divided into $4-\mu \mathrm{L}$ aliquots (about $0.2 \mu \mathrm{g} \cdot \mu \mathrm{L}^{-1}$ ) and frozen $\left(-80^{\circ} \mathrm{C}\right)$.

\section{RT-PCR}

Initial assessment of cerebral cortical eNOS messenger RNA (mRNA) levels was performed by standard RT-PCR and agarose gel electrophoresis with newly generated primers based on the rat complementary DNA (cDNA) sequence (GeneTool 1.0; BioTools Inc, Edmonton, Alberta, Canada) (Table E1). Measurement of a standard control gene (glyceraldehyde-3-phosphate dehydrogenase [GAPDH]) was performed with previously described primers to provide RNA measurements of a reference gene that was not expected to change in response to CPB or anemia. The OneStep RT-PCR Kit was used for quantification of RNA levels according to the manufacturer's protocol (Qiagen Inc, Mississauga, Ontario, Canada). Serial dilutions were used to determine whether the generation of RT-PCR product was linear with respect to the amount of RNA used for reverse transcription. All PCR products underwent standard agarose gel electrophoresis. On each $1.5 \%$ agarose gel, RT-PCR product from a single sham and CPB cerebral cortex sample were loaded in triplicate. Gel band densities were digitized and quantified with a computerized digital imaging system (AlphaImager, 8-bit digital camera; Canberra Packard, Toronto, Ontario, Canada). All band densities are expressed in pixels. This method was performed to establish whether cerebral cortical eNOS expression was increased after CPB. After this finding was established, all other assessments were performed by quantitative RT-PCR as described below.

Quantitative RT-PCR was performed by established methods. In brief, reverse transcription of $1 \mu \mathrm{g}$ of total RNA to cDNA was performed with the use of the Moloney-Murine Leukemia Virus
Reverse Transcriptase and random primers, according to the manufacturer's protocol (Invitrogen, Burlington, Ontario, Canada). Real-time quantitative PCR was performed by measuring the SYBR Green fluorescent dye incorporation during double-strand DNA synthesis using the ABI 7900HT Sequence Detection System (Applied Biosystems, Foster City, Calif). With the use of the described ABI method, gene-specific primers for GAPDH, eNOS, and $\mathrm{VEGF}_{164}$ were designed to be suitable for annealing at $62^{\circ} \mathrm{C}$, ranging in size from 23 to 26 bases (Table E1). The PCR product size limitation was between 95 and 350 bases. Gene-specific PCR products were generated with DNA polymerase (SYBR Green PCR Master Mix; Applied Biosystems). In brief, 40 PCR cycles were performed including denaturing at $95^{\circ} \mathrm{C}$ for 15 seconds, annealing, and extension at $62^{\circ} \mathrm{C}$ for 1 minute. The target transcript quantities were determined by measuring the PCR product against a 5-point standard curve. The standard curves were generated for GAPDH, eNOS, and VEGF using a double-stranded DNA template constructed to match the sequence between the $5^{\prime}$ ends of the forward and reverse primers, relative to their cDNAs (Qiagen/Operon). The standard curve values ranged from 10 to $0.001 \mathrm{pg}$ for GAPDH. For the target genes eNOS and $\mathrm{VEGF}_{164}$, standard curve values ranged from 1000 to $0.1 \mathrm{fg}$. Quantitative PCR products are reported in picograms or femtograms. Once PCR products were obtained, melting curve analysis was performed to verify the specificity and identity of the PCR products. Assessment of VEGF was included because this gene is known to be upregulated by hypoxia. Measurement of VEGF mRNA levels helped to determine whether any significant degree of renal or cerebral hypoxia occurred in the CPB animals.

\section{Statistical Analyses}

Statistical analyses were performed with the Statistical Package for the Social Sciences for Windows, version 11.0.0 (SPSS Inc, Chicago, Ill). Physiologic data were assessed for any time and group effect by a 2-way analysis of variance for main and interaction effects. Post hoc analysis was performed by the Tukey test. RTPCR data were assessed by a Kruskal-Wallis 1-way analysis of variance on ranks and post hoc Dunn test. Data are reported as mean \pm standard deviation.

\section{Results}

\section{Physiologic Data: Hemoglobin Concentration and} Blood Gas Analysis

In all three groups, the core temperature and mean arterial pressure remained stable without any significant differences between groups at any time period (Figure 1). There were no differences between groups in baseline hemoglobin concentrations (Figure 1). As intended, the hemoglobin concentration decreased in the sham and both CPB groups according to the protocol. There were no significant differences in hemoglobin concentration between the CPB and sham groups at any time (Figure 1). In the CPB anemia group, a more severe degree of hemodilution was performed. Thus, the hemoglobin concentration in the CPB anemia group remained significantly lower than that in the CPB group at all time points during CPB (Figure 1, $64 \pm$ $\left.5 \mathrm{~g} \cdot \mathrm{L}^{-1}, P<.001\right)$. Arterial blood gas data demonstrated 

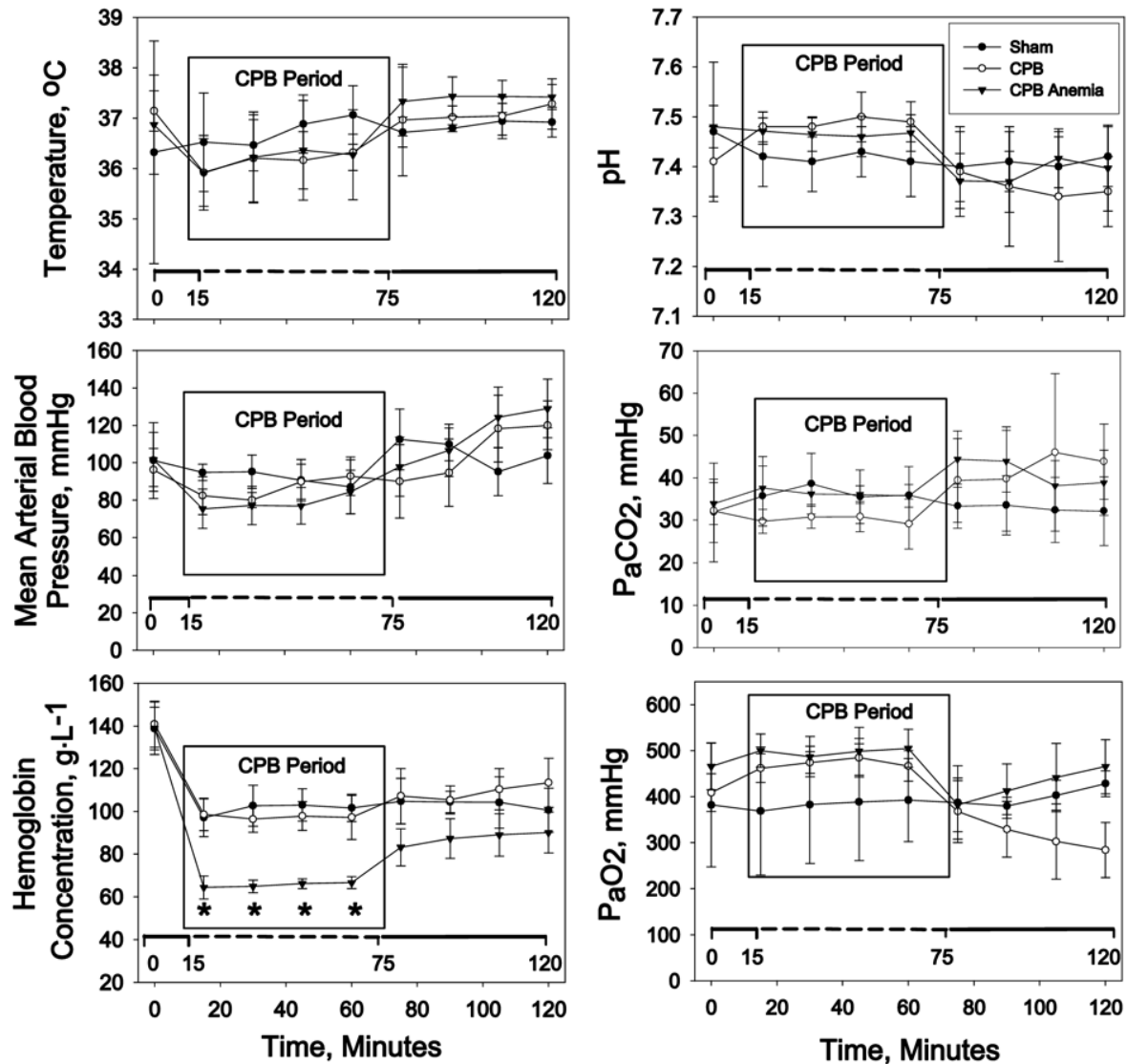

Figure 1. Left panels, Rectal temperature (upper left panel), mean arterial pressure (middle left panel), and hemoglobin concentration (lower left panel) in sham (closed circle), CPB (open circle), and CPB anemia (closed triangle) rats. The initial measurement at baseline was compared with values during 1 hour of CPB (CPB, 15 to 75 minutes). The initial drop in hemoglobin occurred as a result of mild hemodilution in sham and CPB rats. This decrease was significantly greater in anemic rats, which underwent a more severe degree of hemodilution. There were no significant differences in mean arterial pressure or temperature between groups. Right panels, pH (upper right panel), $\mathrm{PaCO}_{2}$ (middle right panel), and $\mathrm{PaO}_{2}$ (lower right panel) in sham, CPB, and CPB anemia rats. There were no significant differences in $\mathrm{pH}, \mathrm{PaCO}_{2}$ and $\mathrm{PaO}_{2}$ when $\mathrm{CPB}, \mathrm{CPB}$ anemia, and sham animals were compared. ${ }^{*} \boldsymbol{P}<.05$ relative to baseline and between groups. $C P B$, cardiopulmonary bypass.

no significant difference in $\mathrm{pH}, \mathrm{PaCO}_{2}$, or $\mathrm{PaO}_{2}$ among sham, $\mathrm{CPB}$, and $\mathrm{CPB}$ anemia animals. In all cases, the $\mathrm{pH}$ was maintained near 7.4, the $\mathrm{PaCO}_{2}$ was near 30 to $40 \mathrm{~mm} \mathrm{Hg}$, and the $\mathrm{PaO}_{2}$ was above $2500 \mathrm{~mm} \mathrm{Hg}$ (Figure 1).

\section{Cerebral Cortical eNOS mRNA Levels (Conventional RT-PCR)}

All PCR products were generated in a linear fashion and produced clear PCR product bands near the expected molecular weight. Agarose gel electrophoresis demonstrated that cerebral cortical eNOS mRNA levels were significantly elevated relative to sham 24 hours after CPB $(9430 \pm 2391$ vs $5408 \pm 2792$ pixels/ng total RNA, $P=.016$ ). There were no significant differences in GAPDH mRNA levels between sham and CPB rats $(3679 \pm 1527$ vs $3566 \pm 1114$ pixels/ng total RNA).

\section{Cerebral Cortical eNOS and VEGF mRNA Levels (Quantitative RT-PCR)}

Confirmation of the increase in cerebral cortical eNOS mRNA after CPB was achieved by using primers to a different segment of the rat eNOS gene (Table E1). Realtime RT-PCR demonstrated an increase in cerebral cortical eNOS mRNA after CPB $(11.2 \pm 4.2 \mathrm{fg})$ relative to sham $(6.3 \pm 1.5 \mathrm{fg})$ (Figure 2, $P=.031)$. No further significant changes in eNOS mRNA levels were measured in the CPB anemia group. Messenger RNA levels for cerebral cortical VEGF were significantly reduced after CPB $(10.9 \pm 5.4 \mathrm{fg})$ 


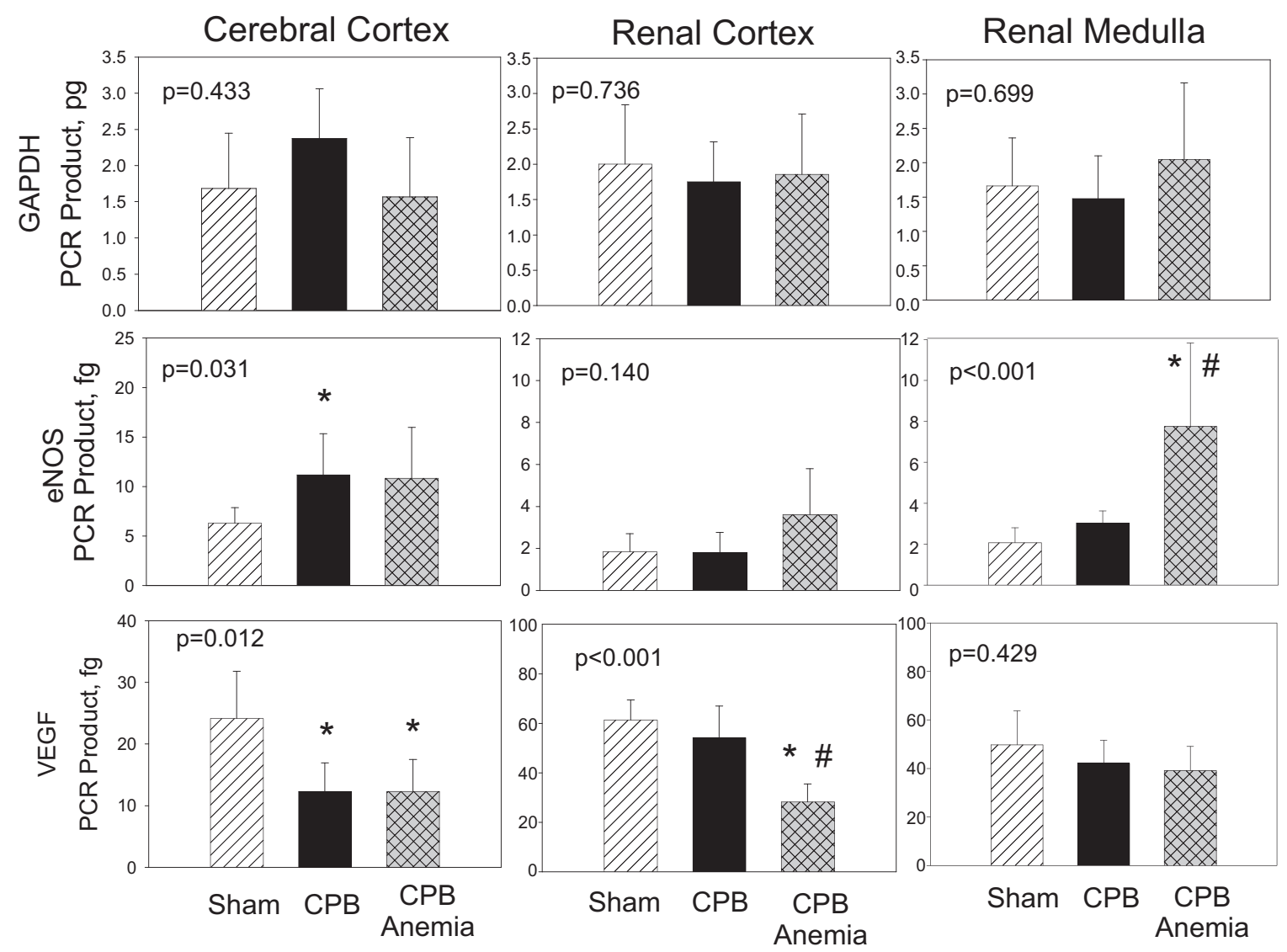

Figure 2. Real time quantitative RT-PCR analyses of GAPDH, eNOS, and VEGF mRNA levels in cerebral cortex, renal cortex, and renal medulla of sham, CPB, and CPB anemia rats. No differences in mRNA levels for the control gene GAPDH were observed among groups in any tissue. Cerebral cortical eNOS mRNA was significantly elevated after CPB, but not further increased by CPB and anemia. In renal cortical tissue, CPB did not result in any significant change in eNOS mRNA levels; however, CPB and anemia tended to increase eNOS expression. In the renal medulla, CPB and anemia resulted in a large increase in eNOS mRNA levels relative to sham and CPB groups. No increase in mRNA was observed for the hypoxic gene VEGF. However, CPB and anemia resulted in a significant reduction in VEGF mRNA levels in both the cerebral and renal cortex. ${ }^{*} \boldsymbol{P}<.05$ relative to sham; $\# \boldsymbol{P}<.05$ relative to the CPB group. PCR, polymerase chain reaction; GAPDH, glyceraldehyde-3-phosphate dehydrogenase; $e N O S$, endothelial nitric oxide synthase; VEGF, vascular endothelial growth factor; mRNA, messenger RNA; CPB, cardiopulmonary bypass.

and CPB anemia (Figure $2, P=.012$ ). By contrast, VEGF mRNA levels were increased after hypoxia exposure $(55.2$ $\pm 18.3 \mathrm{fg})$ relative to sham animals $(24.2 \pm 7.6 \mathrm{fg})(P=$ .016). No differences in GAPDH mRNA levels were observed among the three groups.

\section{Renal Cortical and Medullary eNOS and VEGF} mRNA Levels (Quantitative RT-PCR)

Renal cortical eNOS mRNA values were not statistically different among groups after CPB, CPB anemia, or sham (sham $1.9 \pm 0.9 \mathrm{fg}, \mathrm{CPB} 1.8 \pm 0.9 \mathrm{fg}$, and CPB anemia 3.6 \pm 2.2 fg, Figure $2, P=.140$ ). By contrast, renal medullary eNOS levels tended to increase after CPB $(3.0 \pm 0.6 \mathrm{fg})$ relative to sham rats $(1.8 \pm 0.4 \mathrm{fg})$ and were significantly elevated in the anemic rats after CPB $(7.8 \pm 4.1 \mathrm{fg}$ ) (Figure $2, P<.001)$. Renal cortical VEGF mRNA levels decreased after CPB in anemic rats (Figure $2, P<.001$ ). No significant changes in renal cortical or medullary GAPDH gene expression were observed.

\section{Discussion}

This study demonstrates that eNOS mRNA levels are elevated compared with sham control values in the cerebral cortex and renal medulla 24 hours after CPB in a rat model of normothermic CPB. Expression of renal medulla eNOS 
was most profoundly influenced by the combination of $\mathrm{CPB}$ and anemia. The increases in eNOS were not accompanied by any significant changes in expression of the control gene GAPDH, suggesting that CPB or the other experimental techniques did not produce a nonspecific increase in gene expression. These data relate to the clinical findings that renal dysfunction after CPB has been associated with low hematocrit and eNOS gene polymorphism, suggesting that this model of CPB may help to define the mechanism by which eNOS many protect from, or contribute to, organ injury after $\mathrm{CPB} .^{2-6}$

Cerebral and renal dysfunction are significant determinants of morbidity and mortality after CPB. In both cases, increased renal and cerebral injury have been associated with the lowest hematocrit on CPB. ${ }^{2-6}$ This suggests that the combination of nonphysiologic circulation and altered cerebral and renal perfusion may potentiate end-organ injury after CPB. Experimental studies have demonstrated that traditional laminar perfusion may be inferior to biologically variable flow that more closely approximates physiologic perfusion conditions. ${ }^{19}$ Therefore, standard continuous-flow CPB may provide suboptimal perfusion characteristics that stimulate compensatory mechanisms to improve organ function, including increased expression of cerebral and renal eNOS. Severe hemodilutional anemia may lead to further reductions in tissue oxygen delivery ${ }^{2,4,5}$ and introduce additional changes in shear forces,${ }^{20}$ which may provide further stimuli for greater eNOS expression. This may explain the magnitude of the increase in renal medullary eNOS expression that occurred in anemic rats after CPB.

Endothelial NOS/nitric oxide is known to play an important role in regulating vascular smooth muscle tone and organ perfusion. ${ }^{14,16,17,21,22}$ As such, greater cerebral and renal eNOS expression after CPB could help to limit endorgan injury. ${ }^{16}$ Endothelial NOS/nitric oxide may also protect against organ injury by limiting systemic inflammation, ${ }^{23}$ inhibiting leukocyte adhesion, ${ }^{24}$ and limiting platelet aggregation. ${ }^{25}$ Increased activity and expression of eNOS has been observed in myocardial tissue of patients undergoing cardiac surgery with $\mathrm{CPB} .{ }^{26,27}$ In addition, eNOS polymorphism has been associated with increased vascular responsiveness to vasocontrictors during CPB in humans. ${ }^{28}$ To our knowledge, this is the first study to examine eNOS expression in the brain and kidney after CPB. We chose to measure gene expression 24 hours after $\mathrm{CPB}$ because other experimental models (hypoxia, brain injury) have demonstrated a maximal biological effect of gene expression 18 to 24 hours after exposure to the stimulus and because cerebral and renal dysfunction may develop or be manifest in this time frame..$^{29,30}$

Although most studies have suggested a protective effect, the possibility that eNOS expression may contribute to organ injury and dysfunction after CPB cannot be excluded.
Experimental models of CPB have implicated a number of candidate mechanisms of injury, which include tissue hypoxia,,${ }^{9,11,12}$ proapoptotic and antiapoptotic factors, ${ }^{10}$ cyclooxygenase, and inflammatory mediators. ${ }^{18,23,31}$ However, the potential role of NOS in the pathophysiology of organ perfusion and/or injury after CPB has not been elucidated.

Demonstration of increased renal medullary eNOS after CPB may have significant physiologic and pathophysiologic implications. ${ }^{14}$ Under resting conditions, relatively high expression of eNOS has been previously demonstrated in the renal medulla. ${ }^{32}$ Furthermore, renal hypoperfusion significantly increases renal medullary, but not cortical, eNOS expression. ${ }^{33}$ Such basal and stimulated expression of eNOS may be important to maintaining adequate perfusion to the relatively hypoxic renal medulla during and after CPB. ${ }^{7}$ In this study, the highest level of renal medullary eNOS was seen in anemic rats undergoing CPB. This increase in eNOS expression may be stimulated by reduced oxygen delivery and/or increased shear stress within the vasculature. ${ }^{20}$ In situations of extreme hemodilution, this and other protective mechanisms may be overwhelmed, resulting in renal injury. ${ }^{2,4}$ Clinical studies have implicated eNOS genotype variation in the pathophysiology of renal injury after $\mathrm{CPB} .{ }^{3}$ Further research is required to assess the role of eNOS in renal injury after CPB.

The greater expression of cerebral and renal eNOS mRNA compared with sham after CPB in rats occurs within 24 hours after recovery from a 1-hour period of experimental CPB. Measurement of cerebral cortical eNOS expression demonstrated a significant increase after CPB with a marginal $P$ value of .031 . This observation was obtained via both standard and quantitative PCR, on different cerebral cortical tissue samples, with specific primers designed to amplify two different regions of the eNOS gene. These two independent measures support the likelihood that the increase in cerebral cortical eNOS expression was a true result. During $\mathrm{CPB}$, there was no evidence of systemic hypotension, hypoxemia, or acidosis, suggesting that these stimuli were not responsible for the increase in eNOS expression.

Regulation of the hypoxic gene VEGF followed a different pattern after CPB. The data demonstrate the following: (1) cerebral cortical VEGF expression was reduced after CPB and CPB anemia; (2) renal cortical VEGF expression was reduced after $\mathrm{CPB}$ and anemia; and (3) renal medullary VEGF mRNA levels did not change significantly in any group. Since VEGF mRNA levels are up-regulated by hypoxia, these responses suggest that significant tissue hypoxia did not occur in either the brain or kidney during or after CPB. Although the mechanism by which eNOS expression is enhanced has not been defined, hypoxia is not a likely candidate on the basis of the observed reduction in VEGF expression. Levels of mRNA for the control gene 
GAPDH did not change significantly in brain or kidney in any of the groups studied, emphasizing that the observed changes in eNOS and VEGF represented specific physiologic regulation of gene expression in response to CPB.

\section{Limitations}

This study has some limitations. We used a previously established and validated model of CPB that does not include sternotomy, cardioplegia, crossclamping, and underlying comorbidities to assess the effect of $\mathrm{CPB}$ on eNOS expression. ${ }^{10,18}$ Therefore, the effect of these clinically relevant factors could not be assessed. The sample size in this study was based on previous data from our and other laboratories, but the possibility of a type II error does exist. Our study measured outcomes at only one time point. This was chosen because other experimental models have demonstrated a maximal biological effect of gene expression approximately 24 hours after exposure to the stimulus. ${ }^{29,30}$ However, without baseline or immediate post-CPB samples, we cannot exclude the possibility of an earlier effect. No measurements of organ perfusion were performed and the link between eNOS mRNA levels and improved organ perfusion is speculative. Histologic examination was not performed on our tissue samples, but previous work with this model found no evidence of gross neuronal injury or necrosis. ${ }^{10}$ Future research will address the physiologic significance, protein expression, and cellular localization of the eNOS expression.

\section{Conclusions}

In summary, experimental $\mathrm{CPB}$ and hemodilution resulted in a significantly higher level of cerebral cortical and renal medullary eNOS mRNA than was observed in similarly anesthetized and instrumented sham animals. This occurred in association with lower VEGF expression, suggesting that tissue hypoxia was not the stimulus for eNOS expression. Recent clinical data suggest that genetic variability in the eNOS gene may contribute to renal dysfunction after CPB. Further basic and clinical research will better define the role of eNOS in cerebral and renal function during and after CPB.

We acknowledge the technical assistance of Ms Carla Coackley and Mr Rong Qu.

\section{References}

1. Newman MF, Kirchner JL, Phillips-Bute B, Gaver V, Grocott H, Jones $\mathrm{RH}$, et al. Longitudinal assessment of neurocognitive function after coronary-artery bypass surgery. N Engl J Med. 2001;344:395-402.

2. Karkouti K, Beattie WS, Wijeysundera DN, Rao V, Chan C, Dattilo $\mathrm{KM}$, et al. Hemodilution during cardiopulmonary bypass is an independent risk factor for acute renal failure in adult cardiac surgery. J Thorac Cardiovasc Surg. 2005;129:391-400.

3. Stafford-Smith M, Podgoreanu M, Swaminathan M, Phillips-Bute B, Mathew JP, Hauser EH, et al. Association of genetic polymorphisms with risk of renal injury after coronary bypass graft surgery. Am $J$ Kidney Dis. 2005;45:519-30.

4. Swaminathan M, Phillips-Bute BG, Conlon PJ, Smith PK, Newman MF, Stafford-Smith M. The association of lowest hematocrit during cardiopulmonary bypass with acute renal injury after coronary artery bypass surgery. Ann Thorac Surg. 2003;76:784-91.

5. Habib RH, Zacharias A, Schwann TA, Riordan CJ, Durham SJ, Shah A. Adverse effects of low hematocrit during cardiopulmonary bypass in the adult: should current practice be changed? J Thorac Cardiovasc Surg. 2003;125:1438-50.

6. Jonas RA, Wypij D, Roth SJ, Bellinger DC, Visconti KJ, du Plessis AJ, et al. The influence of hemodilution on outcome after hypothermic cardiopulmonary bypass: results of a randomized trial in infants. J Thorac Cardiovasc Surg. 2003;126:1765-74.

7. Stafford-Smith M, Grocott HP. Renal medullary hypoxia during experimental cardiopulmonary bypass: a pilot study. Perfusion. 2005;20: 53-8.

8. Whitaker DC, Newman SP, Stygall J, Hope-Wynne C, Harrison MJ, Walesby RK. The effect of leucocyte-depleting arterial line filters on cerebral microemboli and neuropsychological outcome following coronary artery bypass surgery. Eur J Cardiothorac Surg. 2004;25:26774.

9. Ma D, Yang H, Lynch J, Franks NP, Maze M, Grocott HP. Xenon attenuates cardiopulmonary bypass-induced neurologic and neurocognitive dysfunction in the rat. Anesthesiology. 2003;98:690-8.

10. Sato Y, Laskowitz DT, Bennett ER, Newman MF, Warner DS, Grocott HP. Differential cerebral gene expression during cardiopulmonary bypass in the rat: evidence for apoptosis? Anesth Analg. 2002;94:138994; table.

11. Mutch WA, Ryner LN, Kozlowski P, Scarth G, Warrian RK, Lefevre GR, et al. Cerebral hypoxia during cardiopulmonary bypass: a magnetic resonance imaging study. Ann Thorac Surg. 1997;64:695-701.

12. Kadoi Y, Saito S, Goto F, Fujita N. Decrease in jugular venous oxygen saturation during normothermic cardiopulmonary bypass predicts short-term postoperative neurologic dysfunction in elderly patients. J Am Coll Cardiol. 2001;38:1450-5.

13. Homi HM, Yang H, Pearlstein RD, Grocott HP. Hemodilution during cardiopulmonary bypass increases cerebral infarct volume after middle cerebral artery occlusion in rats. Anesth Analg. 2004;99:974-81.

14. Ortiz PA, Garvin JL. Cardiovascular and renal control in NOS-deficient mouse models. Am J Physiol Regul Integr Comp Physiol. 2003; 284:R628-38.

15. Hudetz AG, Wood JD, Kampine JP. 7-Nitroindazole impedes erythrocyte flow response to isovolemic hemodilution in the cerebral capillary circulation. J Cereb Blood Flow Metab. 2000;20:220-4.

16. Tsui SS, Kirshbom PM, Davies MJ, Jacobs MT, Greeley WJ, Kern FH, et al. Nitric oxide production affects cerebral perfusion and metabolism after deep hypothermic circulatory arrest. Ann Thorac Surg. 1996;61:1699-707.

17. Plochl W, Liam BL, Cook DJ, Orszulak TA. Cerebral response to haemodilution during cardiopulmonary bypass in dogs: the role of nitric oxide synthase. Br J Anaesth. 1999;82:237-43.

18. Podgoreanu MV, Michelotti GA, Sato Y, Smith MP, Lin S, Morris RW, et al. Differential cardiac gene expression during cardiopulmonary bypass: ischemia-independent upregulation of proinflammatory genes. J Thorac Cardiovasc Surg. 2005;130:330-9.

19. Graham MR, Warrian RK, Girling LG, Doiron L, Lefevre GR, Cheang $\mathrm{M}$, et al. Fractal or biologically variable delivery of cardioplegic solution prevents diastolic dysfunction after cardiopulmonary bypass. J Thorac Cardiovasc Surg. 2002;123:63-71.

20. Boo YC, Hwang J, Sykes M, Michell BJ, Kemp BE, Lum H, et al. Shear stress stimulates phosphorylation of eNOS at $\operatorname{Ser}(635)$ by a protein kinase A-dependent mechanism. Am J Physiol Heart Circ Physiol. 2002;283:H1819-28.

21. Joshi S, Young WL, Duong DH, Ostapkovich ND, Aagaard BD, Hashimoto T, et al. Intracarotid infusion of the nitric oxide synthase inhibitor, L-NMMA, modestly decreases cerebral blood flow in human subjects. Anesthesiology. 2000;93:699-707.

22. Jones SC, Easley KA, Radinsky CR, Chyatte D, Furlan AJ, PerezTrepichio AD. Nitric oxide synthase inhibition depresses the height of 
the cerebral blood flow-pressure autoregulation curve during moderate hypotension. J Cereb Blood Flow Metab. 2003;23:1085-95.

23. Hayashi Y, Sawa Y, Fukuyama N, Nakazawa H, Matsuda H. Inducible nitric oxide production is an adaptation to cardiopulmonary bypassinduced inflammatory response. Ann Thorac Surg. 2001;72:149-55.

24. Kubes P, Suzuki M, Granger DN. Nitric oxide: an endogenous modulator of leukocyte adhesion. Proc Natl Acad Sci U S A. 1991;88: 4651-5.

25. Radomski MW, Palmer RM, Moncada S. An L-arginine/nitric oxide pathway present in human platelets regulates aggregation. Proc Natl Acad Sci U S A. 1990;87:5193-7.

26. Mayers I, Hurst T, Puttagunta L, Radomski A, Mycyk T, Sawicki G, et al. Cardiac surgery increases the activity of matrix metalloproteinases and nitric oxide synthase in human hearts. $J$ Thorac Cardiovasc Surg. 2001;122:746-52.

27. Bloch W, Mehlhorn U, Krahwinkel A, Reiner M, Dittrich M, Schmidt A, et al. Ischemia increases detectable endothelial nitric oxide synthase in rat and human myocardium. Nitric Oxide. 2001;5:317-33.

28. Philip I, Plantefeve G, Vuillaumier-Barrot S, Vicaut E, LeMarie C, Henrion D, et al. G894T polymorphism in the endothelial nitric oxide synthase gene is associated with an enhanced vascular responsiveness to phenylephrine. Circulation. 1999;99:3096-8.

29. Guo Y, Ward ME, Beasjours S, Mori M, Hussain SN. Regulation of cerebellar nitric oxide production in response to prolonged in vivo hypoxia. J Neurosci Res. 1997;49:89-97.

30. Kuo NT, Benhayon D, Przybylski RJ, Martin RJ, LaManna JC. Prolonged hypoxia increases vascular endothelial growth factor mRNA and protein in adult mouse brain. J Appl Physiol. 1999;86:260-4.

31. Hindman BJ, Moore SA, Cutkomp J, Smith T, Ross-Barta SE, Dexter $F$, et al. Brain expression of inducible cyclooxygenase 2 messenger RNA in rats undergoing cardiopulmonary bypass. Anesthesiology. 2001;95:1380-8

32. Teichert AM, Miller TL, Tai SC, Wang Y, Bei X, Robb GB, et al. In vivo expression profile of an endothelial nitric oxide synthase promoterreporter transgene. Am J Physiol Heart Circ Physiol. 2000;278:H135261 .

33. Abassi Z, Gurbanov K, Rubinstein I, Better OS, Hoffman A, Winaver J. Regulation of intrarenal blood flow in experimenta heart failure: role of endothelin and nitric oxide. Am J Physiol. 1998;274:F766-74. 
TABLE E1. Summary of primers used for standard and real-time quantitative RT-PCR

\begin{tabular}{|c|c|c|c|c|c|c|c|}
\hline Primer & Primer sequence $\left(5^{\prime}-3^{\prime}\right)$ & Start, bp & End, bp & Size, bp & Anneal temp, ${ }^{\circ} \mathrm{C}$ & Cycle & $\begin{array}{l}\text { Accession number/ } \\
\text { (reference) }\end{array}$ \\
\hline \multicolumn{8}{|c|}{ Primers for standard RT-PCR } \\
\hline \multicolumn{8}{|c|}{ GAPDH } \\
\hline Forward & ACC ACC ATG GAG AAG GCT GG & 331 & 858 & 527 & 60 & 20 & $\begin{array}{l}\text { M17701 (Bona E, Pediatr } \\
\quad \text { Res 1999;45:500-9) }\end{array}$ \\
\hline $\begin{array}{l}\text { Reverse } \\
\text { eNOS }\end{array}$ & CTC AGT GTA GCC CAG GAT GC & & & & & & \\
\hline $\begin{array}{l}\text { Forward } \\
\text { Reverse }\end{array}$ & $\begin{array}{l}\text { CCC CCA GAC GGA CCC AAG TTT } \\
\text { GGG AAC ACC GTG ATG GCT GAA C }\end{array}$ & 188 & 699 & 511 & 62 & 32 & AF085195 \\
\hline \multicolumn{8}{|c|}{ Primers for quantitative RT-PCR } \\
\hline $\begin{array}{l}\text { Forward } \\
\text { Reverse }\end{array}$ & $\begin{array}{l}\text { CTC TAA GGC TGT GGG CAA GGT CAT } \\
\text { GAG ATC CAC CAC CCT GTT GCT GTA }\end{array}$ & 655 & 998 & 343 & 62 & 40 & AF106860 \\
\hline eNOS & & & & & & & \\
\hline $\begin{array}{l}\text { Forward } \\
\text { Reverse }\end{array}$ & $\begin{array}{l}\text { TTG TGG ACC ACC ATG CCG CCA CAG } \\
\text { AAG ACA GGG GTG AGG CTG CCT G }\end{array}$ & 1247 & 1376 & 129 & 62 & 40 & XM 342615 \\
\hline $\begin{array}{l}\text { VEGF }_{164} \\
\quad \text { Forward } \\
\text { Reverse }\end{array}$ & $\begin{array}{l}\text { CAT AGG AGA GAT GAG CTT CCT GC } \\
\text { CTC TGA ACA AGG CTC ACA GTG ATT TTC }\end{array}$ & 13 & 109 & 96 & 62 & 40 & AF260425 \\
\hline
\end{tabular}

$\overline{R T-P C R}$, reverse transcriptase polymerase chain reaction; $b p$, base pair; GAPDH, glyceraldehyde-3-phosphate dehydrogenase; eNOS, endothelial nitric oxide synthase; VEGF, vascular endothelial growth factor. 